\title{
Recent Injuries of External Genitalia: Clinical Aspects and Management
}

\author{
Kimassoum Rimtebaye1, Kaboro Mignagnal1, Arya Zarif Agah Tashkand, \\ Franklin Danki Sillong2, Lamine Niang3, Gueye Serigne Magueye ${ }^{3}$ \\ ${ }^{1}$ Hopital Général de Référence Nationale, N’Djamena, Chad \\ ${ }^{2}$ Hopital Protestant de N'Gaoundéré, N'Gaoundéré, Cameroun \\ ${ }^{3}$ Hopital Grand Yoff de Dakar, Dakar, Sénégal \\ Email: melinarim@yahoo.fr, Kaboro2@hotmail.com, arya.agah@gmail.com, danki franklin@yahoo.fr
}

Received 31 July 2015; accepted 6 September 2015; published 9 September 2015

Copyright (C) 2015 by authors and Scientific Research Publishing Inc.

This work is licensed under the Creative Commons Attribution International License (CC BY).

http://creativecommons.org/licenses/by/4.0/

(c) $\underset{\mathrm{EY}}{\mathrm{B}}$ Open Access

\begin{abstract}
Aim: Report the epidemiological, clinicopathological characteristics and ensuring management of recent traumas of the external genitalia in Urology. Methods: This was a descriptive retrospective study of 47 cases of patients suffering from recent traumas of the external genitalia over a period of 5 years. The variables studied were sociodemographic, clinical, paraclinical, therapeutic and evolutionary. Results: A total of 47 patients, including 46 men, were managed. The mean age was 26.8 years, ranging from 6 to 56 years. The circumstances of occurrence were: the missteps of coitus $(n=$ 16), traffic accidents $(n=9)$ and criminal injuries $(n=8)$. The fracture of the penis $(n=16)$ was the most common lesion followed by the scrotal wound $(n=11)$. The management was medical and surgical and varied by the type of lesion. The outcome was favorable in $91.5 \%$ of cases. Conclusion: The incidence of traumas of the external genitalia was 9.4 in urology department in N'Djamena. Penis fracture was the frequent lesion. The management is multidisciplinary, medical and surgical.
\end{abstract}

\section{Keywords}

Coitus, Scrotum, Penis, External Genitalia, Urology

\section{Introduction}

Recent traumas of the external genitalia (RTEG) are common in men and rare in women [1] [2]. Due to their anatomical location and instinct of protection that they enjoy, the external genitalia are not exposed to traumatic injuries [3]. Particular attention is given to external genital because of their functions: urinary and sexual.

Trauma of external genitalia represents $2 \%-10 \%$ of injuries in general and $27 \%-68 \%$ of genitourinary

How to cite this paper: Rimtebaye, K., Mignagnal, K., Zarif Agah Tashkand, A., Danki Sillong, F., Niang, L. and Serigne Magueye, G. (2015) Recent Injuries of External Genitalia: Clinical Aspects and Management. Open Journal of Urology, 5, 161166. http://dx.doi.org/10.4236/oju.2015.59025 
trauma [4] [5].

The causes are many and varied, with significant place for "faux-pas du coït" and traffic accidents. The lesions are diverse and sometimes very serious that can jeopardize not only the functional prognosis, but also fertile prognosis of the patient and require urgent care. The lesions often encountered include: fracture of the penis during coitus, thermal burns of external genitalia, criminal or accidental amputation of the penis, bruising of the scrotum and its contents, amputation of the glans during the circumcision, avulsion of the penile skin and tearing of the scrotal skin, bleeding wounds complicating the excision of young girls... The location and diagnosis of different lesions are most often evident. Additional examinations including ultrasound, scanner and magnetic resonance imaging (MRI) can sometimes be necessary for definitive diagnosis but should not delay the treatment.

Technical advances, particularly in urological endoscopy, have revolutionized the treatment of these lesions. When recognized early and surgically repaired, a good functional result regarding micturition and erection can be expected.

The purpose of this study, the first in Chad, was to determine the circumstances of occurrence, causes, risk factors, wounding objects, and management.

\section{Material and Methods}

This was a prospective and descriptive study, involving 47 cases of patients victims of RTEG, received in urology department of the National General Reference Hospital (HGRN). Were included all patients of both sexes, victims of RTEG, came in urology consult or referral from a health district, hospitalized, managed and followed up in the urology department of the HGRN with a complete medical file detailing the anatomical lesions and specific care. Were excluded victims of RTEG not followed or who refused the proposed care. The informed consent of each patient was obtained for the anonymous use of medical records for scientific purposes. The ethics committee of the National Order of Physicians of Chad gave its approval before the start of the study. The variables studied were:

- Epidemiological: age, sex, consultation period, circumstances of occurrence, wounding objects.

- Clinics: general condition, seat and type of injury, associated lesions.

- Paraclinical: ultrasound, retrograde urethrocystography, radiographs of the pelvis, semen analysis for patients over 16 years old.

- Therapeutic: medical and surgical treatment (cystocatheter, cystostomy, trimming, urethroplasty, plasty of the corpora cavernosa). For dilapidated wounds of scrotum, a trimming was done and a directed healing.

- Evolutionary: after medical discharge, patients were regularly followed up every 3 months over a period of 2 years. This follow up was to judge the cosmetic result of external genitalia, the quality of urination and sexual intercourse.

○ Healing was assessed by clinical examination during follow-up consultations in normal or keloid.

- Urination was assessed by flow measurement (normal or slow).

- Erection was judged on the rating scale of the erection of 1 to 5.

- Sexual intercourse were appreciated in the interrogation: possible and satisfactory.

\section{Results}

During our study period, 47 cases of patients victims of RTEG were followed up, wich present an incidence of 9.4. The mean age of patients was 26.8 years, ranging from 6 and 56. Age group the most represented was that 26 - 35 years (Figure 1). The male sex was the most affected with a sex ratio of 46/1. One case of female genital mutilation (Figure 2). In 76.60\% of cases, patients had a consultation within 24 hours after the accident. In $95.70 \%$ of cases, patients had consulted in urology. Circumstances of occurrence were represented by trauma during sexual intercourse and traffic accidents (Table 1). The workplace and dress for work were exposure factors to the risk of accident and injury of external genitalia (Table 2, Figure 3). The lesion was unique and isolated in $89.60 \%$ of cases $(n=42)$. The general condition was kept at $91.50 \%$ of patients. The lesion interested penis (Figure 4) in $46.80 \%$ and $27 \%$ in the scrotum. The trauma was open in $51.07 \%$ of cases. The fracture of the penis was the frequent lesion (34\%), three complicated urethral injury. Two cases of external genitalia burns with hot water. The most incriminated blunt objects were in a decreasing order: knife, razor blade, the bullet, the iron bar. Ultrasonography was the most requested examination to confirm the diagnosis followed by retrograde 


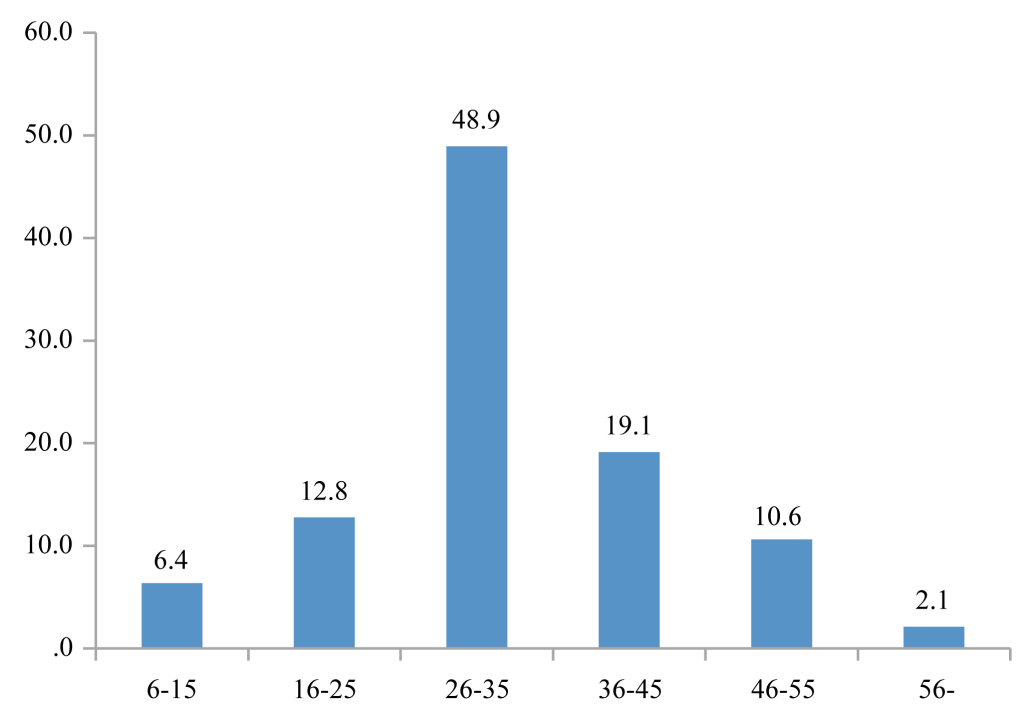

Figure 1. Distribution of cases by age.

Table 1. Distribution of cases according to circumstance of occurrence.

\begin{tabular}{ccc}
\hline Circumstance of Occurrence & Effective & Percentage (\%) \\
\hline Traffic accident & 9 & 19.1 \\
Work accident (including 1 penile amputation) & 4 & 8.5 \\
Criminal trauma & 8 & 17 \\
Sexual intercourse trauma & 16 & 34.0 \\
Animal bite (penile amputation) & 2 & 4.3 \\
An animal hoof blow & 1 & 2.1 \\
Accidental trauma by firearm & 1 & 2.1 \\
Psychogenic amputation of the penis & 3 & 6.4 \\
Female genital mutilation & 1 & 2.1 \\
Iatrogenic trauma & 1 & 2.1 \\
playful accident & 1 & 2.1 \\
Total & 47 & 100.0 \\
\hline
\end{tabular}

Table 2. Distribution of cases by risk factor related to the profession.

\begin{tabular}{ccc}
\hline Profession & Effective & Percentage (\%) \\
\hline $\begin{array}{c}\text { Port of “grand boubou" by an employee in a mill } \\
\text { Bricklayer working in high places without } \\
\text { protection measure }\end{array}$ & 1 & 2.13 \\
Breeder close behind the animal & 2 & 4.25 \\
Others & 1 & 2.13 \\
Total & 43 & 91.48 \\
\end{tabular}




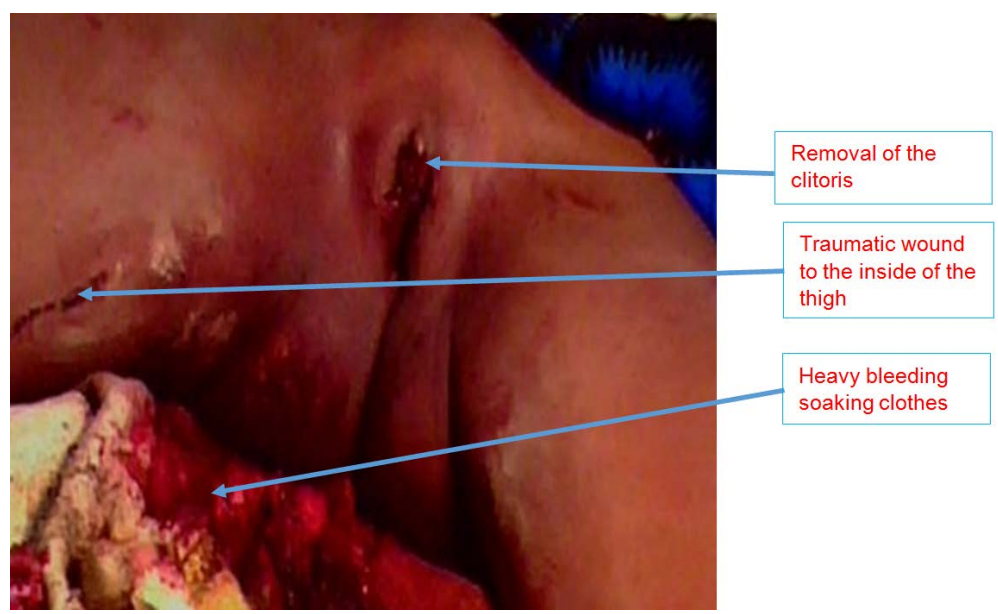

Figure 2. Haemorrhage complicating genital mutilation at a 6-year-old girl.

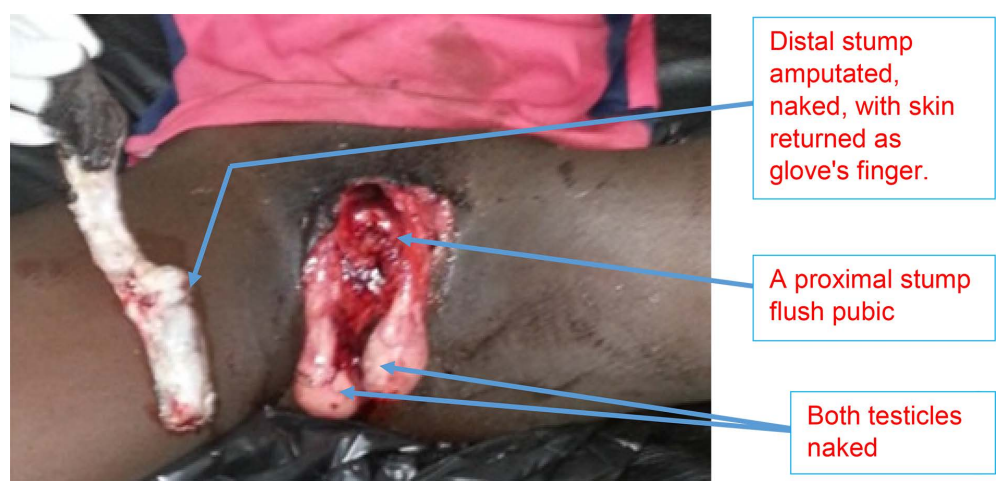

Figure 3. Amputation by mill belt.

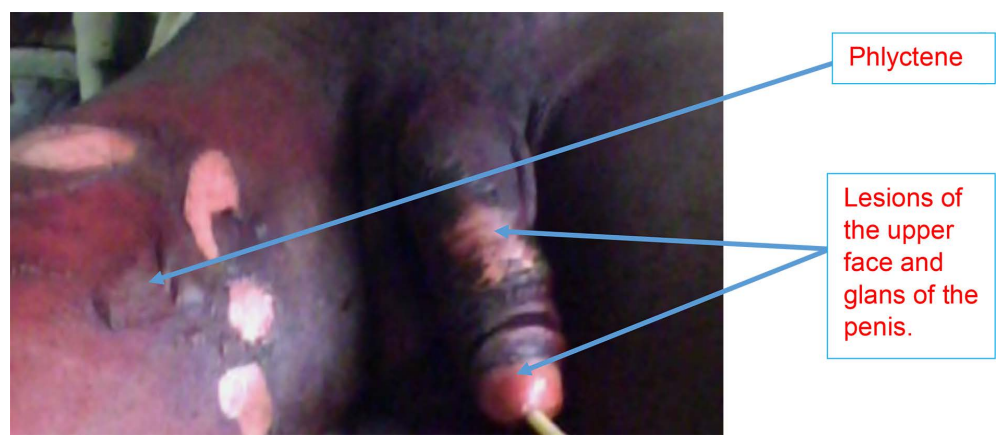

Figure 4. Burning of the penis and the inner face of the right thigh by hot water.

urethrocystography. In $4.2 \%(n=2)$, radiography objectified a fractured pelvis. The treatment was medical and surgical in $95.7 \%$. The emergency surgical treatment consisted of debridement of lesions in $66 \%$. In total, $91.5 \%$ of patients received emergency treatment versus 8.5\%, using anurethroplasty. The evolution after treatment was favorable in $91.5 \%$ of cases: satisfactory appearance. The semen analysis was normal in 8 patients with dilapidated wounds scrotum, three testicular atrophy and one total azoospermia.

\section{Discussion}

In 5 years, 1750 patients were hospitalized, 797 were operated for various urological pathologies, including 47 (5.9\%) for recent traumas of the external genitalia (RTEG). 
Many African authors [2] [6]-[9] recognize that RTEG occurred with predilection in a young adult population — professionally and sexually active as emphasized by our study. Multiple motorcycle accidents, vicious sexual intercourses, urban violence were aggravating factors.

The scarcity of external genitalia lesions in women is underlined by Kambou T et al. [7] which in 12 years related a single case. Male dominance is explained by the externalized position of external genitalia but also by the risk of penis fracture in the age group of 20 - 40 years. Only a 6 years old girl was followed up in emergency care for bleeding after traditional excision of the clitoris for initiatory goal. The prohibition of female genital mutilation in Chad is wishful thinking.

Patients consultedas earlier as the lesion was open. External genitalia are considered noble organs. Their lesions develop in victims feelings of stress, anxiety and fear [10] which motivate early consultation.

The stabbing port is ordinary in Chad unpunished even in schools. The use of blunt objects by the "executioners" sufficiently demonstrates the lack of civility and the degree of barbarity holders who feel a sense of pride after committing their crime.

For McGeady JB and BN Breyer, [4] the RTEG rarely cause a deterioration of the general state which must evoke an associated lesion, finding also highlighted in our study where this young victim population presents a satisfactory condition at admission.

Lakmichi MA et al. [6] in Morocco in 2012 reported the prevalence of external genitalia lesions due to sexual intercourse missteps. For Rimtebaye K et al. [11], sexual intercourse happens with greater force because the boy wants to prove his manliness to his partner by adopting vicious positions.

Two cases on the six of amputation of the penis deserve special attention. The amputation by hippo bite during swimming. Note that in Chad the average temperature is around 45 degree Celsius in the shade during the hottest periods of the year (February to May). It was during this period that men and animals seek the coolness of the river where bites accidents can occur. Amputation by the belt of a mill employee dressed in a "grand boubou". Amputation by the belt of a mill of an employee wearing a "grand boubou" The literature does not mention dress as a risk factor of external genitalia trauma. The mill belt had cut the penis flush to the pubis and scrotal skin was torn off leaving both testes exposed.

An attempted penile reimplantation ended in failure for the patient who was amputated by mill belt. No penile reimplantation was made for the other five patients by lack of availability of the amputated distal stump. The distal stump was either hidden by the schizophrenic patient or carried away by the aggressor. In addition to the care provided to all patients, animal bite victims received a tetanus and rabies serum therapy. Lakmichi MA et al. [12] in 2011 reported a case of total amputation of the penis after the bite by a mule which the victim received a reimplantation.

The urethra lesion was managed in an urethroplasty according to Marion Kelly technique on urinary catheter guardian. Benjelloun $\mathrm{M}$ et al. [13] reported a complication rate of $82 \%$ for medical treatment and $40 \%$ for surgical treatment. Rimtebaye $\mathrm{K}$ et al. [11] reported that medically treated penis fractures were complicated by: fibrosis (misdiagnosed as the lapeyronie disease), kinking, deviation of the penis and erectile dysfunction.

Lakmichi MA et al. [6] operating in 20 patients suffering from open trauma of the scrotum, reported 7 cases of testicular atrophy. Diallo AB et al. [14] point out that subsequent fertility is almost always compromised in RTEG because of the risk of anti sperm autoimmunity.

For cases of burns from hot water, it was a criminal act committed by the wives of the victims. These victims received a cystostomy bypass before dysuria caused by inflammatory edema. The burns of external genitalia by hot water have a criminal origin, done by patient's wives.

The ballistic trauma of external genitalia seems to be rare [8] [10] [15].

\section{Conclusions}

Recent trauma of external genitalia was frequent at the urology department of the HGRN. The victims were young men. Circumstances of occurrence were dominated by the missteps of coitus causing the penis fracture, traffic accident and criminal injuries.

The blunt objects were knife, razor blade, bullet, the iron bar used by attackers, showed lower levels of citizenship.

The imagery was not essential to the diagnosis and did not cause a delay in the management.

The care in emergency and in deferred, was function of the type of lesion and allowed to patients to have 
good quality of urination, cosmetic result and fertility.

Prevention must go through strict regulation of driving licenses in Chad, civic education of the population, wearing proper work clothes. This study examined the lesions involving the external genitalia. The cosmetic and functional results are satisfactory in the short term (2-year follow-up). Further study is needed to determine the fertile future of these patients.

\section{References}

[1] Paulhac, P., Desgrandchamps, F., Teillac, P. and Le Duc, A. (1998) Recent Trauma of Male External Genitalia. Encycl. Med. Chir. Paris, Elsevier, 41, 417.

[2] Dekou, A., Konan, P.G., Kouame, B., Vodi, C., Ouegnin, G.A., Kouame, N., et al. (2008) Trauma of the Genitourinary Tract: Epidemiological and Lesional Aspects. In: Les traumatismes de l’appareil génito-urinaire: Aspects épidémiologiques et lésionnels. African Journal of Urology, 14, 105-113. http://dx.doi.org/10.1007/s12301-008-0001-4

[3] Moufid, K., Joual, A., Debbagh, A., Bennani, S. and El Mrini, M. (2004) Genital Self Mutilation: Report of 3 Cases. In: L'automutilation génitale: À propos de 3 cas. Progres en Urologie, 14, 540-543.

[4] McGeady, J.B. and Breyer, B.N. (2013) Current Epidemiology of Genitourinary Trauma. Urologic Clinics of North America, 40, 323-334. http://dx.doi.org/10.1016/j.ucl.2013.04.001

[5] Djakovic, N., Plas, E., Martínez-Piñeiro, L., Lynch, Th., Mor, Y., Santucci, R.A., et al. (2009) Guidelines on Urological Trauma. European Association of Urology, 82. http://www.uroweb.org/guidelines/online-guidelines/

[6] Lakmichi, M.A., Kabour, J., Sadiki, B., Zahraoui, R., Jarir, R., Wakrim, B., et al. (2012) Challenges and Constraints of the Surgical Management of External Genitalia Traumas in Man Experience of Ten Years (154 Patients). In: Défis et contraintes de la prise en charge chirurgicale des traumatismes des organes génitaux externes chez l'homme expérience de dix ans (154 patients). Progres en Urologie, 22, 764. http://dx.doi.org/10.1016/j.purol.2012.08.056

[7] Kambou, T., Ouattara, A., Zaré, C., Ouattara, A.M., Pare, A.K. and Sanon, B.G. (2014) Urogenital Traumas: Epidemiological Profile and Lesional Aspects at the University Hospital Souro Sanon of Bobo Dioulasso (Burkina Faso). In: Traumatismes urogénitaux: Profil épidémiologique et aspects lésionnels au centre hospitalier universitaire Souro Sanon de Bobo Dioulasso (Burkina Faso). Uro’Andro, 1, 83-90.

[8] Diao, B., Ndoye, A.K., Fall, P.A., Berthe, H., Ondo, C.Z., Niang, L., et al. (2007) Trauma of Scrotums: About 14 Cases. In: Traumatismes des bourses: A propos de 14 observations. African Journal of Urology, 13, 151-156.

[9] Hodonou, R.K., Diallo, A., Akpo, E.C., Koura, A., Hounasso, P.P. and Goudote, E. (1997) Trauma of Male External Genitalia. About 20 Cases. In: Traumatismes des organes génitaux externes masculins (Togem). A propos de 20 cas. Ann Urol, 31, 318-321.

[10] Bah, I., Diallo, A.B., Diao, B., N’doye, M., Gueye, S.M., Diallo, M.B., et al. (2006) External Genitalia Lesions by Firearm. About Six Observations at the Hospital A. Le Dantec, Dakar, Senegal. In: Les lésions des organes génitaux externes par arme à feu. A propos de six observations à l’hôpital A. Le Dantec, Dakar, Sénégal. African Journal of Urology, 12, 55-59.

[11] Rimtebaye, K., Danki, S.F., Ndoye, M. and Vadandi, V. (2015) Fracture of the Penis, Clinical Aspects and Management, about 14 Cases. In: Fracture de la verge, aspects cliniques et prise en charge, à propos de 14 cas. Uro'Andro, 1, 153-156.

[12] Lakmichi, M.A., Wakrim, B., Jarir, R., Dahami, Z., Moudouni, M.S. and Sarf, I. (2011) Mule Bite to the Male Genitalia with Complete Penile and Anterior Urethra Amputation: Unusual Case and Review of the Literature. ISRN Urology, Article ID: 723154.

[13] Benjelloun, M., Rabii, R., Bennani, S., Querfani, B., Joual, A. and El Mrini, M.N. (2003) The Fracture of the Corpus Cavernosum: About 123 Cases. In: La fracture du corps caverneux: A propos de 123 cas. AJOL, 9, 48-52.

[14] Diallo, A.B., Ndoye, A., Fall, P.A., Ba, M., Sylla, C. and Diagne, B.A. (2001) Lesions of the Scrotum by Plugging: A Rare Accident Underwater Fishing. In: Plaie de la bourse par embrochage: Un accident rare de pêche sous-marine. Progres en Urologie, 11, 334-335.

[15] García-Perdomo, H.A. (2014) Importance of Defining the Best Treatment of a Genital Gunshot Wound: A Case Report. World Journal of Clinical Cases, 2, 587-590. http://dx.doi.org/10.12998/wjcc.v2.i10.587 